\title{
A review on the Pramehahara dravya of Bhavaprakash nighantu
}

\author{
Review Article
}

\author{
Prasanna Lakshmi $\mathbf{M}^{1^{*}}$, Suguna Jyothy $\mathrm{P}^{2}$, Madhusudhan Rao $\mathrm{K}^{3}$ \\ 1. PG Scholar, 2. Professor and HOD, 3. Associate Professor \\ Department of Dravyaguna, Dr. NRS Government Ayurvedic College, Vijayawada
}

\begin{abstract}
In Ayurveda, Prameha is considered as one of the serious disease (maharoga) and is considered as difficult to cure disease (yapya roga). It is mainly characterized by the hazy urination and frequent micturition. The disease is comparable with the Diabetes Mellitus of the modern times. The treatments and medicine used for the Prameha in Ayurveda proved to be effective in the management of Diabetes since a long time. Classification of the Pramehahara dravya mentioned the classical Ayurvedic texts helps for the further research on the age old drugs and to provide better medicines for the future. Hence an attempt has been made to find out the plants mentioned as Pramehahara in the most authentic text of the Ayurveda, Bhavaprakash Nighantu, and to critically analyze them on the basis of their properties as mentioned. From the observations it has been noted that dravya having tikta, kashaya rasa, laghu, ruksha guna, katu vipaka play a major role in the management of the Prameha.
\end{abstract}

Keywords: Prameha, Diabetes mellitus, Bhavaprakasha nighantu.

\section{Introduction}

Prameha is one of the diseases mentioned in the Ayurvedic Literature, characterized by the polyuria and haziness of the urine. This is considered as one of the major diseases which proves to be fatal and difficult to treat. Patients lose energy and vigour thus it leads to the weakness and inability to work or do their normal daily activities. $(1,2,3)$ The disease is mentioned even in the Vedic literature, showing that the disease was prevalent even during the time of Vedas. The disease is said as difficult to cure (yapya) and should be maintained with the proper medication. $(2,3)$

Congenital (sahaja), improper diet (apathy nimittaja) and excessive food intake (Santarpanajanya) are the cause mentioned for the disease. All these causes indicate to vitiate the kapha dosha in the body and this kapha leads to the disruption in the functions of all the dhatus in the body. The symptoms of the disease include the presence of plague or other dirty accumulation in the tooth, burning sensation in the palms and soles, bad odour from the body, excess sweating and thirst, excess urination. The disease is again sub classified into 20 types based on the predominance of the dosha. $(1,2,3,4,5)$

The same may be compared with the Diabetes mellitus of the present day Medical science. Diabetes is an endocrine disorder, where insulin production is less in the body leading to the improper regulation of the glucose metabolism. It is characterized with polyuria,

\footnotetext{
*Corresponding Author:
}

\section{Prasanna Lakshmi M,}

PG Scholar, Department of Dravyaguna,

Dr. NRS Government Ayurvedic College, Vijayawada

E-mail: prasanna.luck99@gmail.com polydipsia and polyphagia. The global diabetics ratio is growing gradually. Hence there is an urgent need to find some effective ways to control the disease.

Bhavaprakash Nighantu is one of the best known Ayurvedic text, composed by Shri Bhavamishra in the 16 th $\mathrm{AD}$, with regard to the knowledge of the plants based on the synonyms and properties of the drugs. Hence the text is selected to find out the list of the dravyas having the Pramehahara property and analyze them. (5)

The present study is taken up to identify the medicinal plants used in the Ayurvedic medicine for the treatment of the Prameha.

The aims and objectives of the study are to find out the dravyas mentioned with the term Pramehahara and to analyze them critically based on the principles of Dravyaguna.

\section{Materials and methods}

Bhavaprakash Nighantu of Shri Bhavamishra, translated to hindi by Padmashree Prof. K.C.Chunekar ji has been taken as the base for the study.

The nighantu part has been searched for the term "Pramehahara" and the drugs mentioned to have the said property were listed out. The properties mentioned for the list of the plants are tabulated and critically analyzed them on the principles of dravyaguna to identify the most probable properties of all the Pramehahara dravya. The observations and results are tabulated and discussed accordingly.

\section{Observations and results}

From the observations it has been identified that 19 dravyas are mentioned to have been included with the term Pramehahara. The list of the dravyas are tabulated as seen in the Table no 1 below. 
International Journal of Ayurvedic Medicine, 2019, 10(2), 136-140

Table no: 1: Showing the list of the plants having the Pramehahara property

\begin{tabular}{|c|c|c|c|c|c|c|c|c|}
\hline $\begin{array}{l}\text { S. } \\
\text { No. }\end{array}$ & $\begin{array}{l}\text { Name of } \\
\text { drugs } \\
\text { (part used) }\end{array}$ & $\begin{array}{l}\text { Botanical name } \\
\text { Family }\end{array}$ & Rasa & Guna & Virya & Vipaka & $\begin{array}{l}\text { Doshagh- } \\
\text { nata } \\
\text { (Karma) }\end{array}$ & $\begin{array}{l}\text { Refer- } \\
\text { ences }\end{array}$ \\
\hline 1 & $\begin{array}{l}\text { Haritaki } \\
\text { (Phala) }\end{array}$ & $\begin{array}{l}\text { Terminalia chebula } \\
\text { (gaertn.) Retz } \\
\text { Combretaceae }\end{array}$ & Kasaya & Ruksha & $\overline{\text { Ushna }}$ & Madhura & KP hara & 6 \\
\hline 2 & $\begin{array}{l}\text { Amalaki } \\
\text { (Phala) }\end{array}$ & $\begin{array}{l}\text { Phyllanthus emblica Linn } \\
\text { Euphorbiaceae }\end{array}$ & Amla & Ruksha & Sita & Madhura & VPK hara & 7 \\
\hline 3 & Pippali (Phala) & $\begin{array}{l}\text { Piper longum L. } \\
\text { Piperaceae }\end{array}$ & Katu & $\begin{array}{l}\text { Laghu, } \\
\text { snigdha }\end{array}$ & $\overline{\text { Ushna }}$ & Madhura & VK hara & 8 \\
\hline 4 & $\begin{array}{l}\text { Katuki } \\
\text { (Mula) }\end{array}$ & $\begin{array}{l}\text { Picrorhiza kurroa Royle } \\
\text { ex Benth. } \\
\text { Scrophulariaceae }\end{array}$ & Tikta & $\begin{array}{l}\text { Laghu, } \\
\text { ruksha }\end{array}$ & Sita & Katu & KP hara & 9 \\
\hline 5 & $\begin{array}{l}\text { Katphala } \\
\text { (Tvak) }\end{array}$ & $\begin{array}{l}\text { Myrica esculenta Buch.- } \\
\text { Ham. ex D.Don } \\
\text { Myricaceae }\end{array}$ & $\begin{array}{l}\text { Kashaya, } \\
\text { tikta, katu }\end{array}$ & $\begin{array}{l}\text { Laghu, } \\
\text { ruksha }\end{array}$ & Ushna & Katu & VK hara & 10 \\
\hline 6 & $\begin{array}{l}\text { Pashanabheda } \\
\text { (Panchanga) }\end{array}$ & $\begin{array}{l}\text { Saxifraga ligulata Wall. } \\
\text { Saxifragaceae }\end{array}$ & $\begin{array}{l}\text { Tikta, } \\
\text { Kashaya }\end{array}$ & $\begin{array}{l}\text { Laghu, } \\
\text { ruksha }\end{array}$ & Sita & Katu & VPK hara & 11 \\
\hline 7 & $\begin{array}{l}\text { Devadaru } \\
\text { (Sara) }\end{array}$ & $\begin{array}{l}\text { Cedrus deodara Roxb. } \\
\text { Pinaceae }\end{array}$ & Tikta & $\begin{array}{l}\text { Snigdha, } \\
\text { Laghu }\end{array}$ & $\overline{\text { Ushna }}$ & Katu & KV hara & 12 \\
\hline 8 & $\begin{array}{l}\text { Guduci } \\
\text { (Kanda,Mula, } \\
\text { patra) }\end{array}$ & $\begin{array}{l}\text { Tinospora cordifolia } \\
\text { Willd. } \\
\text { Menispermaceae }\end{array}$ & $\begin{array}{l}\text { Tikta, } \\
\text { Kashaya }\end{array}$ & Laghu & $\overline{\text { Ushna }}$ & Madhura & VPK hara & 13 \\
\hline 9 & $\begin{array}{l}\text { Gokshura } \\
\text { (Phala,Mula) }\end{array}$ & $\begin{array}{l}\text { Tribulus terrestris Linn. } \\
\text { Zygophyllaceae }\end{array}$ & Madhura & $\begin{array}{l}\text { Guru, } \\
\text { Snigdha }\end{array}$ & Sita & Madhura & VPhara & 14 \\
\hline 10 & $\begin{array}{l}\text { Mahanimba } \\
\text { (Mula,Tvak) }\end{array}$ & $\begin{array}{l}\text { Melia azaderach Linn. } \\
\text { Meliaceae }\end{array}$ & $\begin{array}{l}\text { Tikta, } \\
\text { Kashaya }\end{array}$ & Ruksha & Sita & Katu & KP hara & 15 \\
\hline 11 & $\begin{array}{l}\text { Karanji } \\
\text { (Mula,Tvak, } \\
\text { Patra,Bija) }\end{array}$ & $\begin{array}{l}\text { Holoptelia integrifolia } \\
\text { Roxb. } \\
\text { Ulmaceae }\end{array}$ & $\begin{array}{l}\text { Tikta, } \\
\text { Kashaya }\end{array}$ & $\begin{array}{l}\text { Ruksha, } \\
\text { Laghu }\end{array}$ & Ushna & Katu & Phara & 16 \\
\hline 12 & Gojihva (Patra) & $\begin{array}{l}\text { Elephantopus scaber L. } \\
\text { Asteraceae }\end{array}$ & $\begin{array}{l}\text { Kashaya, } \\
\text { tikta }\end{array}$ & Laghu & Sita & Madhura & KP hara & 17 \\
\hline 13 & $\begin{array}{l}\text { Dhava } \\
\text { (Tvak) }\end{array}$ & $\begin{array}{l}\text { Anogeissus latifolia Wall. } \\
\text { Combretaceae }\end{array}$ & $\begin{array}{l}\text { Madhura, } \\
\text { Kashaya }\end{array}$ & $\begin{array}{l}\text { Laghu, } \\
\text { Ruksha }\end{array}$ & Sita & Katu & PKhara & 18 \\
\hline 14 & Katabhi (Tvak) & $\begin{array}{l}\text { Careya arborea Roxb. } \\
\text { Lecythidaceae }\end{array}$ & $\begin{array}{l}\text { Kasahya, } \\
\text { katu }\end{array}$ & Laghu & $\overline{\text { Ushna }}$ & Katu & Khara & 19 \\
\hline 15 & Tinisha (Tvak) & $\begin{array}{l}\text { Ougeinia dalbergioides } \\
\text { Benth. } \\
\text { Fabaceae }\end{array}$ & Kashaya & Laghu & Uhsna & katu & KP hara & 20 \\
\hline 16 & Amra pushpa & $\begin{array}{l}\text { Mangifera indica Linn. } \\
\text { Anacardiaceae }\end{array}$ & Kashaya & Laghu & Sita & katu & KP hara & 21 \\
\hline 17 & $\begin{array}{l}\text { Tinduka } \\
\text { (Phala) }\end{array}$ & $\begin{array}{l}\text { Diospyros embryopteris } \\
\text { Pers } \\
\text { Ebenaceae }\end{array}$ & Madhura & Guru & Sita & Madhura & PRK hara & 22 \\
\hline 18 & $\begin{array}{l}\text { Bruhalloni } \\
\text { (Pancanga) }\end{array}$ & $\begin{array}{l}\text { Portulaca quadrifolia } \\
\text { Linn. } \\
\text { Portulacaceae }\end{array}$ & Amla & $\begin{array}{l}\text { Guru, } \\
\text { Ruksha }\end{array}$ & $\overline{\text { Ushna }}$ & Amla & PKhara & 23 \\
\hline 19 & Kebuka (Patra) & $\begin{array}{l}\text { Cheilocostus speciosus } \\
\text { (J.Konig) C.Specht. } \\
\text { Zingiberaceae }\end{array}$ & Katu, amla & Laghu & Sita & Katu & KP hara & 24 \\
\hline
\end{tabular}




\section{Results}

From the dravyas identified and the properties of them that are tabulated as mentioned in Table no 1, the dravyas are analyzed based on the Rasa, Guna, Virya, Vipaka and Karma on the dosha.

Based on the rasa is has been observed that out of the 19 dravyas identified, it has been observed that madhura rasa is observed in 3 dravyas, amla rasa in 3 , lavana rasa in 0 , katu rasa in 3, tikta rasa in 9 and Kashaya rasa in 11 dravyas. (Graph 1)

Based on the guna is has been observed that out of the 19 dravyas identified, it has been observed that laghu guna is observed in 12, ruksha guna in 9, snigdha guna in 3 and guru guna in 3 dravyas. (Graph 2)

\section{Graph 1: Showing the distribution of Pramehahara dravyas according to the rasa}

RASA

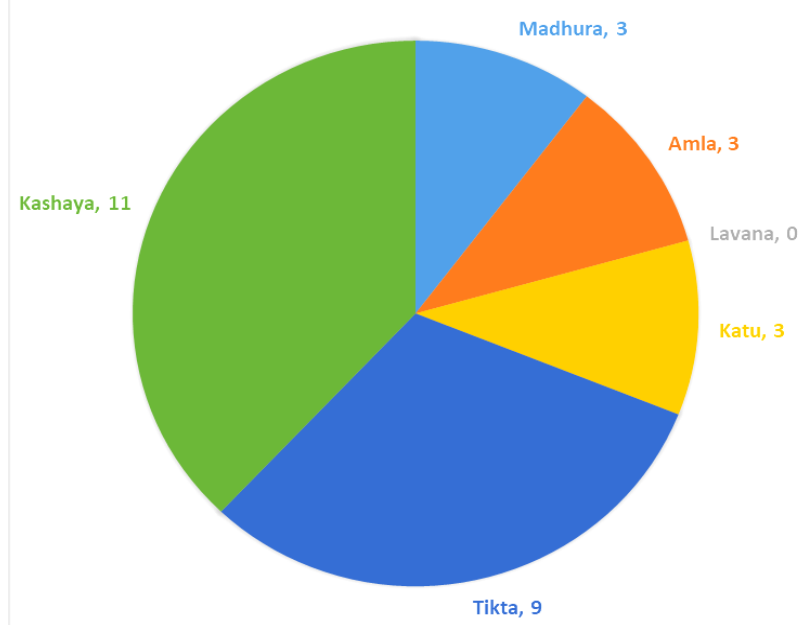

Graph 3: Showing the distribution of Pramehahara dravyas according to the virya

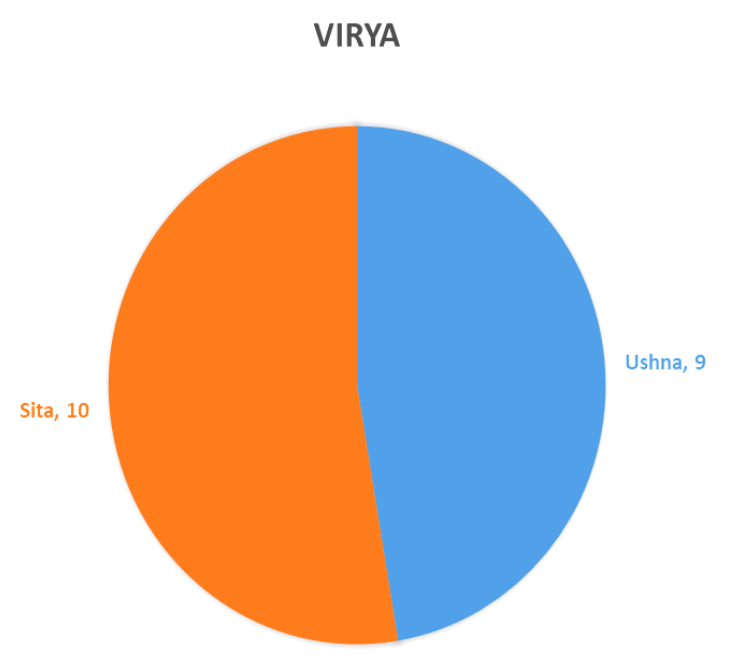

Based on the virya is has been observed that out of the 19 dravyas identified, it has been observed that ushna virya is observed in 11 dravyas whereas sita virya is observed in 10 dravya. (Graph 3)

Based on the vipaka is has been observed that out of the 19 dravyas identified, it has been observed that Madhura vipaka is observed in 7 dravya, amla vipaka in 1 and katu vipaka in 11 dravya. (Graph 4)

Based on the karma is has been observed that out of the 19 dravyas identified, it has been observed that 1 dravya is vatahara, 1 pittahara, 1 kaphahara, 0 vatapittahara, 10 pittakaphahara, 3 vatakaphahara and 3 tridosha hara. (Graph 5)

\section{Graph 2: Showing the distribution of Pramehahara dravyas according to the gunas}

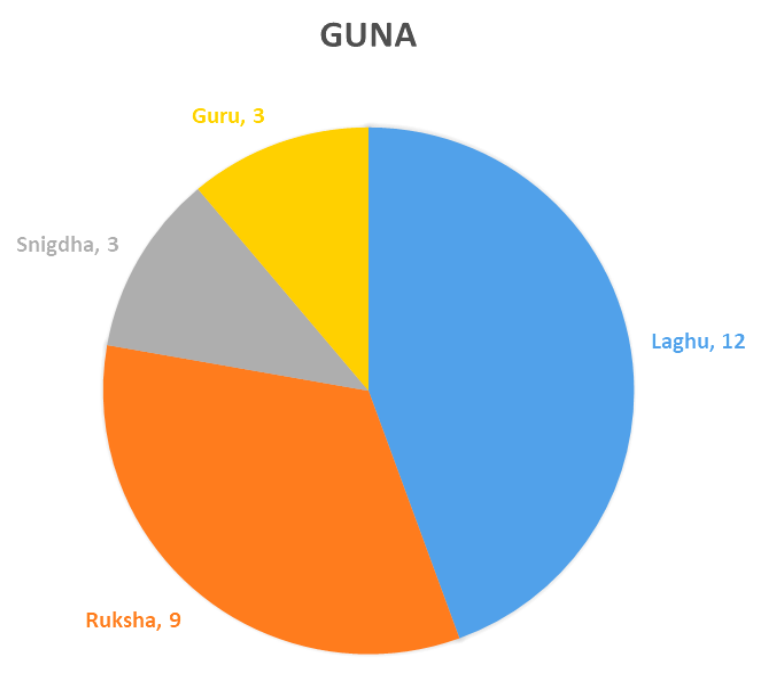

Graph 4: Showing the distribution of Pramehahara dravyas according to the Vipaka

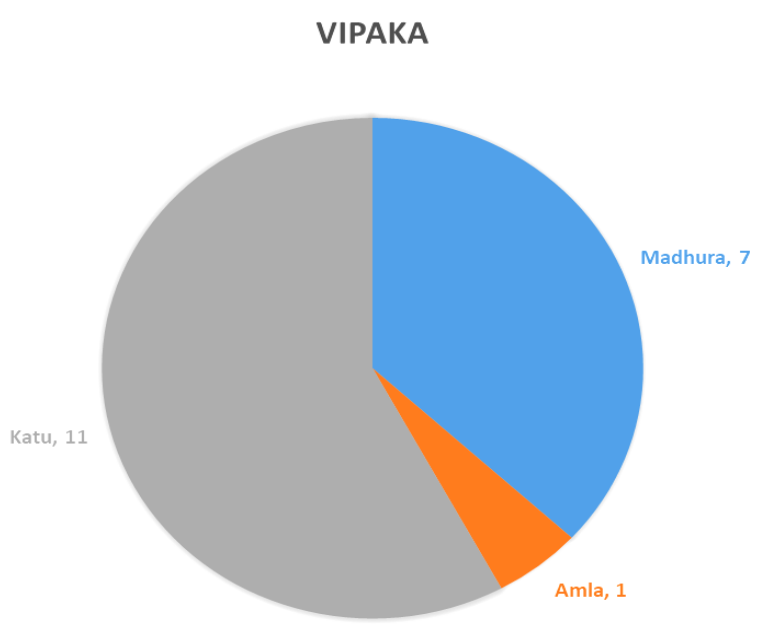




\section{Graph 5: Showing the distribution of Pramehahara dravyas according to the dosha karma}

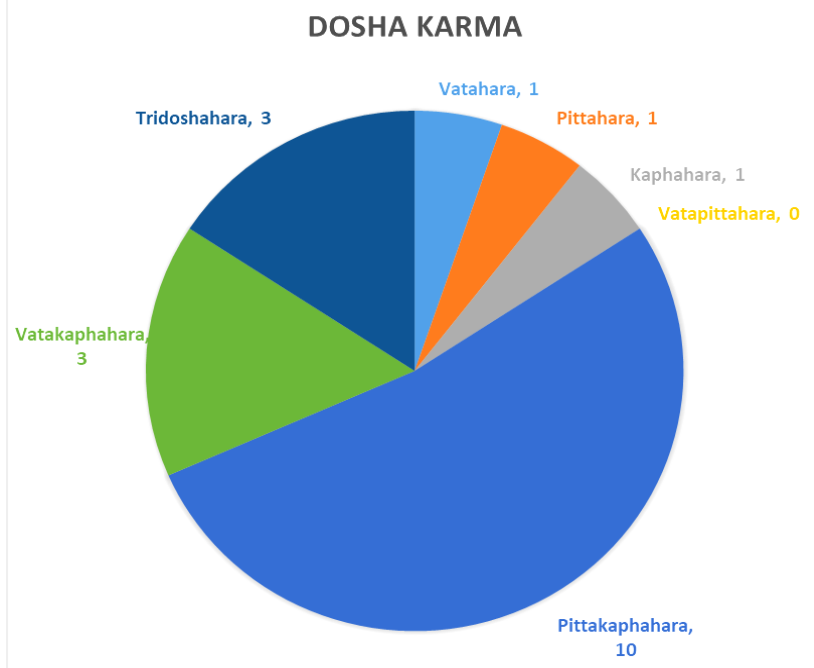

\section{Discussion}

Prameha is primarily a santarpanajany vyadhi i.e., it is caused by the improper dietietic habits. The foods that increase the kapha dosha leads to the increase in the kapha dosha and vitiates the vata and pitta doshas. Thus all the doshas get involved in the causation of the disease. The vitiated doshas disturb the dhatus lke meda, rakta, shukra, lasika, vasa, majja, rasa and ojus and expels them out of the body in the form of hazy and frequent urination. So the initial step in the aetiology of the prameha is the vitiation of the kapha dosha. Kapha dosha as mentioned in the Ayurvedic texts is predominant in the guru, snigdha and sita gunas, madhura, amla and lavana rasa are the aggrevating rasas to kapha. Sita virya and madhura vipaka also leads to the vitiation of the kapha and leads to Prameha. $(1,2,3)$

Clinically Prameha rogi is classified into two types i.e, stula Pramehi and Krusha pramehi. If the prameha rogi is having strength then he is called as stula pramehi and if the strength is low then he is considered as krusha pramehi. For the management of the stula pramehi guru apatarpana dravya are mentioned whereas for the krusha pramehi laghu santarpana dravya are mentioned. (1)

From the observations and results obtained it has been noted that the most of the dravyas listed are having tikta and kashaya rasa. This indicates that most of the kashaya and tikta rasa dravya are useful to reduce the kapha and reduce the disease prameha.

Laghu and ruksha gunas are predominant in the dravyas, showing that the prameha can be cured with the usage of laghu, ruksha guna, which are opposite in the qualities of the kapha dosha.

With regard to the virya no much variation has been observed both ushna and sita virya dravyas are found equally indicating that both the dravya act on prameha depending upon the condition of the patient.
Katu vipaka dravyas are more compared to amla and madhura vipaka dravya. Because the madhura and amla vipaka promote the kapha dosha whereas katu vipaka counteracts the kapha dosha and reduces it.

With regard to the karma most of the dravyas are pitta kapha hara karma. As in most of the case of the Prameha tridosha are involved with the primary involvement of kapha dosha and pitta dosha getting affected by the excessive accumulation of the kapha.

Thus from the above it can be observed that most of the dravya involved have laghu, ruksha guna, tikta, Kashaya rasa, katu viapaka as their properties.

\section{Conclusion}

Thus from the above study it can be concluded that dravyas having laghu, ruksha guna, tikta, Kashaya rasa, katu vipaka and ushna virya will have better Pramehahara properties. The drugs which are not mentioned in the Ayurvedic texts but having the above mentioned properties can be tried clinically to achieve the Pramehahara effect.

\section{References}

1. http://niimh.nic.in/ebooks/ecaraka/index.php dt 14-05-2019.

2. http://niimh.nic.in/ebooks/esushruta/index.php dt 16-05-2019.

3. Shrikanta Murhty KR. Ashtanga Hridayam, nidanasthana English translation. Chaukhambha Publication, Varanasi. p. 92-99.

4. Shrikanta Murhty KR. Madhava Nidana English translation, Chaukhambha Krishnadas Acaemy, Varanasi. p. 116-119

5. Indradev Tripathi, Dayashankar Tripathy. Yogaratnakara, Chaukhambha Academy, Varanasi. p. 622-41.

6. Chunekar. KC. Bhavapraksha nighantu Hindi translation, Chaukhambha publications, Varanasi. p. 3-9.

7. Chunekar. KC. Bhavapraksha nighantu Hindi translation, Chaukhambha publications, Varanasi. p. 10.

8. Chunekar. KC. Bhavapraksha nighantu Hindi translation, Chaukhambha publications, Varanasi. p. 15.

9. Chunekar. KC. Bhavapraksha nighantu Hindi translation, Chaukhambha publications, Varanasi. p. 69.

10. Chunekar. KC. Bhavapraksha nighantu Hindi translation, Chaukhambha publications, Varanasi. p. 100.

11. Chunekar. KC. Bhavapraksha nighantu Hindi translation, Chaukhambha publications, Varanasi. p. 105.

12. Chunekar. KC. Bhavapraksha nighantu Hindi translation, Chaukhambha publications, Varanasi. p. 196. 
13. Chunekar. KC. Bhavapraksha nighantu Hindi translation, Chaukhambha publications, Varanasi. p. 239.

14. Chunekar. KC. Bhavapraksha nighantu Hindi translation, Chaukhambha publications, Varanasi. p. 292.

15. Chunekar. KC. Bhavapraksha nighantu Hindi translation, Chaukhambha publications, Varanasi. p. 331.

16. Chunekar. KC. Bhavapraksha nighantu Hindi translation, Chaukhambha publications, Varanasi. p. 343.

17. Chunekar. KC. Bhavapraksha nighantu Hindi translation, Chaukhambha publications, Varanasi. p. 471.

18. Chunekar. KC. Bhavapraksha nighantu Hindi translation, Chaukhambha publications, Varanasi. p. 539.
19. Chunekar. KC. Bhavapraksha nighantu Hindi translation, Chaukhambha publications, Varanasi. p. 543.

20. Chunekar. KC. Bhavapraksha nighantu Hindi translation, Chaukhambha publications, Varanasi. p. 547.

21. Chunekar. KC. Bhavapraksha nighantu Hindi translation, Chaukhambha publications, Varanasi. p. 551.

22. Chunekar. KC. Bhavapraksha nighantu Hindi translation, Chaukhambha publications, Varanasi. p. 567.

23. Chunekar. KC. Bhavapraksha nighantu Hindi translation, Chaukhambha publications, Varanasi. p. 670 .

24. Chunekar. KC. Bhavapraksha nighantu Hindi translation, Chaukhambha publications, Varanasi. p. 701. 